\title{
Clinical and demographic pattern of chronic granulomatous disease (CGD) from a multicenter perspective: Malaysia's experience over 26 years
}

Lokman Mohd Noh ${ }^{1,2^{*}}$ (0), Amir Hamzah Abdul Latiff ${ }^{3}$, Intan Hakimah Ismail ${ }^{4}$, Rahim Md Noah ${ }^{5}$, Asrul Abdul Wahab ${ }^{6}$, Intan Juliana Abd. Hamid ${ }^{7}$, Adiratna Mat Ripen ${ }^{8}$, Nasuruddin B. Abdullah',10, Kamarul Azhar Razali ${ }^{11}$, Norzila Zainudin ${ }^{12,13}$, Florence Bakon ${ }^{14}$, Long Juan Kok ${ }^{15}$, Adli Ali ${ }^{16}$, Bilkis Banu SAbd Aziz ${ }^{16}$, Hasniah Abdul Latif ${ }^{16}$, Siti Mardhiana Mohamad ${ }^{17}$, Zarina Thasneem Zainudeen ${ }^{7}$, Ilie Fadzilah Hashim7, lean Hamzah Sendut ${ }^{18,19}$, Thiyagar Nadarajaw ${ }^{20}$, Faizah Mohamed Jamil ${ }^{21}$, David C. E. $\mathrm{Ng}^{22,23}$ and Mohd Azri Zainal Abidin ${ }^{4}$

\begin{abstract}
Background: A retrospective review of clinical manifestations and demographic pattern of patients diagnosed as chronic granulomatous disease (CGD) from 7 hospitals in Malaysia. An analysis of the available database would establish clinical characteristics, diagnoses and outcome including microbiologic pattern. Studying the demography allows us to document the occurrence of CGD amongst multiethnic groups and its geographical distribution for Malaysia.

Methods: Data from the Malaysia Primary Immunodeficiency Network (MyPIN) with cases of CGD diagnosed from 1991 until 2016 were collated and analysed.

Results: Twenty patients were diagnosed as CGD. Males $(N=13,65 \%)$ outnumber females $(N=7,35 \%)$. CGD is commonest amongst the Malays (65\%) followed by the Chinese (15.0\%), Indians (10.0\%) and natives of Borneo (10.0\%), reflecting the ethnic composition of the country. The mean age of diagnosis was 3.7 years. There was a positive family history in $40 \%$ of the cases. Abscess was the main presenting feature in 16 patients (80\%) with one involving the brain. Pneumonia occurred in 10 (50\%) and one with complicated bronchiectasis. Catalase-positive bacteria were the most commonly isolated pathogen with Chromobacterium violaceum predominating ( $N=5,25 \%)$ with consequent high mortality $(N=4,80 \%)$. All CGD patients with C. violaceum infection displayed CD4+ (T helper cells) lymphopenia.
\end{abstract}

Conclusion: This study has shown CGD occurs in the major ethnic groups of Malaysia. To the best of our knowledge, this is the first and the largest series of chronic granulomatous disease in South East Asia which may be reflective of similar clinical pattern in the region. C. violaceum infection is associated with a higher mortality in CGD patients

*Correspondence: lokman.m.noh@gmail.com

${ }^{1}$ Department of Paediatrics, Hospital Tunku Azizah, Ministry of Health Malaysia, Kuala Lumpur, Malaysia

Full list of author information is available at the end of the article

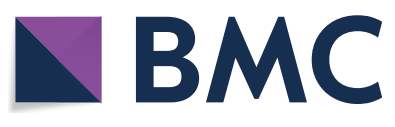

(c) The Author(s) 2021. This article is licensed under a Creative Commons Attribution 4.0 International License, which permits use, sharing, adaptation, distribution and reproduction in any medium or format, as long as you give appropriate credit to the original author(s) and the source, provide a link to the Creative Commons licence, and indicate if changes were made. The images or other third party material in this article are included in the article's Creative Commons licence, unless indicated otherwise in a credit line to the material. If material is not included in the article's Creative Commons licence and your intended use is not permitted by statutory regulation or exceeds the permitted use, you will need to obtain permission directly from the copyright holder. To view a copy of this licence, visit http://creativeco mmons.org/licenses/by/4.0/. The Creative Commons Public Domain Dedication waiver (http://creativecommons.org/publicdomain/ zero/1.0/) applies to the data made available in this article, unless otherwise stated in a credit line to the data. 
in Malaysia. All the CGD patients with C. violaceum infection in this patient series displayed CD4 + (T helper) lymphopenia. We recorded rare clinical manifestation of CGD viz. brain abscess and bronchiectasis.

Keywords: Chronic granulomatous disease, Malaysia, Clinical, Demographic pattern, Chromobacterium violaceum, CD4 + lymphopenia

\section{Background}

Chronic granulomatous disease (CGD) is a genetic disorder resulting from the defect of one of the subunits of enzyme NADPH oxidase. It is responsible for the production of the reactive oxygen species (ROS) by the phagocytes to kill the engulfed pathogen. Defects of this enzyme predispose the susceptible individual to infection mainly by catalase-positive organisms. The mode of inheritance may be further classified into X-linked inheritance (mutation in CYBB gene) and autosomal recessive inheritance (mutation in either CYBA, CYBC1, NCF1, NCF2 and NCF4 genes) [1].

The prevalence of the disease is not well described in many developing countries. A study in the United States (US) estimated the incidence of CGD is between 1 in 200,000 to 1 in 250,000 live births [2]. A systematic review on published primary immunodeficiency disease (PID) in Malaysia showed that CGD was the third most common reported form of PID, which is comparable with Singapore's PID cohort [3]. Chronic granulomatous disease cases in Malaysia were first reported in 1994 diagnosed in two unrelated boys [4] based on nitroblue tetrazolium dye test (NBT) and chemiluminescence assay (CA); and this would have been the first report from South East Asia (SE Asia). Few countries in SE Asia (Malaysia, Singapore and Thailand) have published reports of case series of PID which included CGD [3-7]. This report would be the first patient series in SE Asia, revealing some inherent differences in the clinical and demographic patterns from the Europe, America and Asia $[2,8-10,18]$

\section{Methods}

Malaysia Primary Immunodeficiency Network (MyPIN) is a collaborative network of clinical immunologists, immunopathologists, scientists and general pediatrician/ physicians managing primary immunodeficiency patients in both government and academic institutions. Patients referred for recurrent infections with a diagnosis of primary immunodeficiency seen in seven hospitals in Malaysia between 1986 and 2016, were entered into data sheets by the corresponding author from the beginning. The seven hospitals were: Institute of Pediatrics, Hospital Kuala Lumpur, Hospital Pantai Kuala Lumpur, Hospital Serdang Selangor, Sarawak General Hospital Kuching, Hospital Canselor Tunku Muhriz, UKM Cheras,
University of Malaya Medical Centre, Kuala Lumpur, Hospital Sultanah Bahiyah, Alor Setar Kedah. In the absence of a National centralized registry for the country this is the most optimal system of record to ensure PID data is preserved. All clinical and immunological data of patients with diagnosis of chronic granulomatous disease were retrieved and analyzed. The diagnosis of CGD was based on clinical features and abnormality of phagocytic function, inability to generate reactive oxygen species [10]. Only 20 could be retrieved with phagocytic function assay that included either NBT and/or CA and/or dihydrorhodamine 123 (DHR) assay in the participating immunology laboratories. NBT and/or CA were the only assays that could be done up to 2010; subsequent diagnostic tests including DHR assay were done by the Advanced Medical and Dental Institute (AMDI), Universiti Sains Malaysia, Penang (AMDI first started this test in 2011 [11]), Institute for Medical Research, Kuala Lumpur and Universiti Putra Malaysia, Serdang. Four patients had mutational assays done (NCF1 and CYBB). Both NBT and CA were done in 4, chemiluminescence assay in 19 and DHR 123 in 4 patients.

\section{Dihydrorhodamine (DHR) test}

Heparinized whole blood was incubated with the various stimuli (unlabeled opsonized E. coli, PMA and fMLP) at $37{ }^{\circ} \mathrm{C}$. A sample without stimulus served as negative background control. Formation of the reactive oxidants during the oxidative burst was monitored by the addition and oxidation of DHR123. The reaction was stopped by addition of lysing solution, and after one washing step with wash solution, DNA staining solution was added to exclude aggregation artifacts of bacteria or cell.

\section{Flow cytometry}

DHR samples were then analyzed by using BD FACSCanto $^{\text {TM }}$ II. Ten thousand viable granulocytes determined by forward and side scatterplot were collected, and FL2 (585 nm) was analyzed. A sample from healthy subject was used as a positive control for each assay. The percentages of cells having produced reactive oxygen radicals were then analyzed as well as the stimulation index (SI) was calculated as the ratio of geometric mean channel fluorescence intensity of PMAstimulated and unstimulated granulocytes. 


\section{Genetic test}

Genetic tests were not universally available for patients in Malaysia. Only 4 were performed and were mainly performed as a research activity, with 3 of the earlier samples for analysis sent to centers overseas.

\section{Results}

\section{Demography of patients}

Twenty patients were diagnosed with CGD either by functional assays of the phagocyte function that included 13 males and 7 females. Genetic mutational assays were available for four patients $(\mathrm{NCF} 1=2$, $\mathrm{CYBB}=2)$. However, defect in $\mathrm{p} 47$ phox protein expression was documented in 6 patients, which were suggestive of autosomal recessive CGD (NCF1 gene mutation).

The mean age onset of symptoms was $2.16 \pm 3.13$ ) years old. The patients were diagnosed between the age of 0.3 to 12 years, with a mean age of diagnosis of $3.7 \pm 3.95)$ years old. Ethnic distribution showed Malays $(\mathrm{N}=13,65 \%)$ was the predominant race, followed by Chinese $15 \%(\mathrm{~N}=3)$, Indians $10 \%(\mathrm{~N}=2)$ and Natives of Borneo $10 \%(\mathrm{~N}=2)$. It is remarkable that $5(25 \%)$ of the CGD patients were from different families residing in Sarawak; a state in East Malaysia with a population that constitute only $9 \%$ of total Malaysia's population. Family history of early death for possible of PID in the first degree relative was obtained in 8 patients $(40 \%)$. Consanguinity was noted in two patients (10\%). Table 1 represents the clinical and demographic presentations of the patients with CGD in Malaysia.

\section{Clinical manifestations and types of infections}

The most common clinical presentation of the patients was abscesses, $(\mathrm{N}=16,80 \%$; skin $=10$, spleen $=3$, liver $=3$, bone $=1$, brain $=1$, muscle $=1$ ) followed by pneumonia $(\mathrm{N}=10,50 \%)$ with one complicating as bronchiectasis. Hepatosplenomegaly (30\%) and lymphadenitis (15\%) were the next common findings. Other sites of infections were listed in Table 2. Mycobacterium tuberculosis infection was diagnosed based on clinical grounds.

\section{Microbiological and immunological profiles}

The microbiological profile of the patients was predominantly of the catalase-positive bacteria as shown in Table 3. Chromobacterium violaceum were isolated from $5(25 \%)$ patients. Melioidosis was diagnosed in 2 children based on high titers to Burkholderia pseudomallei. Staphylococcus spp. was isolated in 2 patients (one with Staphylococcus aureus and one with Staphylococcus epidermidis) from skin abscesses specimens. Bacterial infections $(\mathrm{N}=13)$ predominated over fungal infections $(\mathrm{N}=3)$.

The immunological parameters of the patients are illustrated in Table 4. Serum immunoglobulin showed hypergammaglobulinemia with elevated IgG, IgA and IgM in 73,86 and $53 \%$ of the cases, respectively. Elevated lymphocyte subsets were also observed, $46 \%$ of the CGD patients had elevated CD3+lymphocyte counts, $27 \%$ with high CD4+and 36\% with high CD8+lymphocyte counts. B cells were elevated in only $20 \%$ of the cases. CD4+lymphopenia was seen in $36.4 \%$ of the cases, with low CD3+and CD8+lymphocyte counts observed in $6.7 \%$ and $18.2 \%$ of CGD patients, respectively. Low immunoglobulin levels were not much affected, ranges between 0 and $6 \%$ of the cases only. Interestingly, all the 4 (100\%) CGD patients with CD4+lymphopenia had been infected with C. violaceum.

\section{Management and outcome of the patients}

Of the patients that could be followed up, 5 (25\%) died, with 4 patients displaying $C$. violaceum infection. It appeared that $C$. violaceum in $C G D$ was associated with high mortality rate $(80 \%)$. Most of the patients received trimethoprim-sulfamethoxazole and itraconazole as an antimicrobial of choice for prophylaxis. None received interferon (IFN) gamma therapy as it was not readily available locally. One patient (P12) received allogeneic hematopoietic stem cell transplantation (HSCT) and is still alive 12 years later [13].

\section{Discussion}

The earliest published report of CGD in Malaysia as case reports was in 1994 compared to India in 1999 and Taiwan in 2000 [14, 15]. There was another report of CGD in Malaysia in 2012 [16]. Herein, we report 20 cases of CGD from 7 hospitals located both in Peninsular and East Malaysia. As with most South East Asian countries, facilities, and resources for PID care in Malaysia are limited; mutational analysis was not available locally until the last decade of which samples had to be sent overseas.

To the best of our knowledge this report of CGD patient series is the first and the largest from SE Asia. The other large series from Thailand is actually a PID series of 67 patients which included 6 CGD patients [7]. The mean age of diagnosis for our patients was 3.7 years, much later than Sri Lanka (1.6 years), and China (2.24 years), but earlier than India (4.6 years) [8, 9, 17].

Chronic granulomatous disease occurs more commonly in males and with X-linked mode of inheritance as seen in two large studies from Europe and the US, where males predominate with the former at $81 \%$ (351 out of 429 ) and the latter at $70.5 \%$ (259 out of 368 patients), respectively [2, 19]. Similar occurrence 


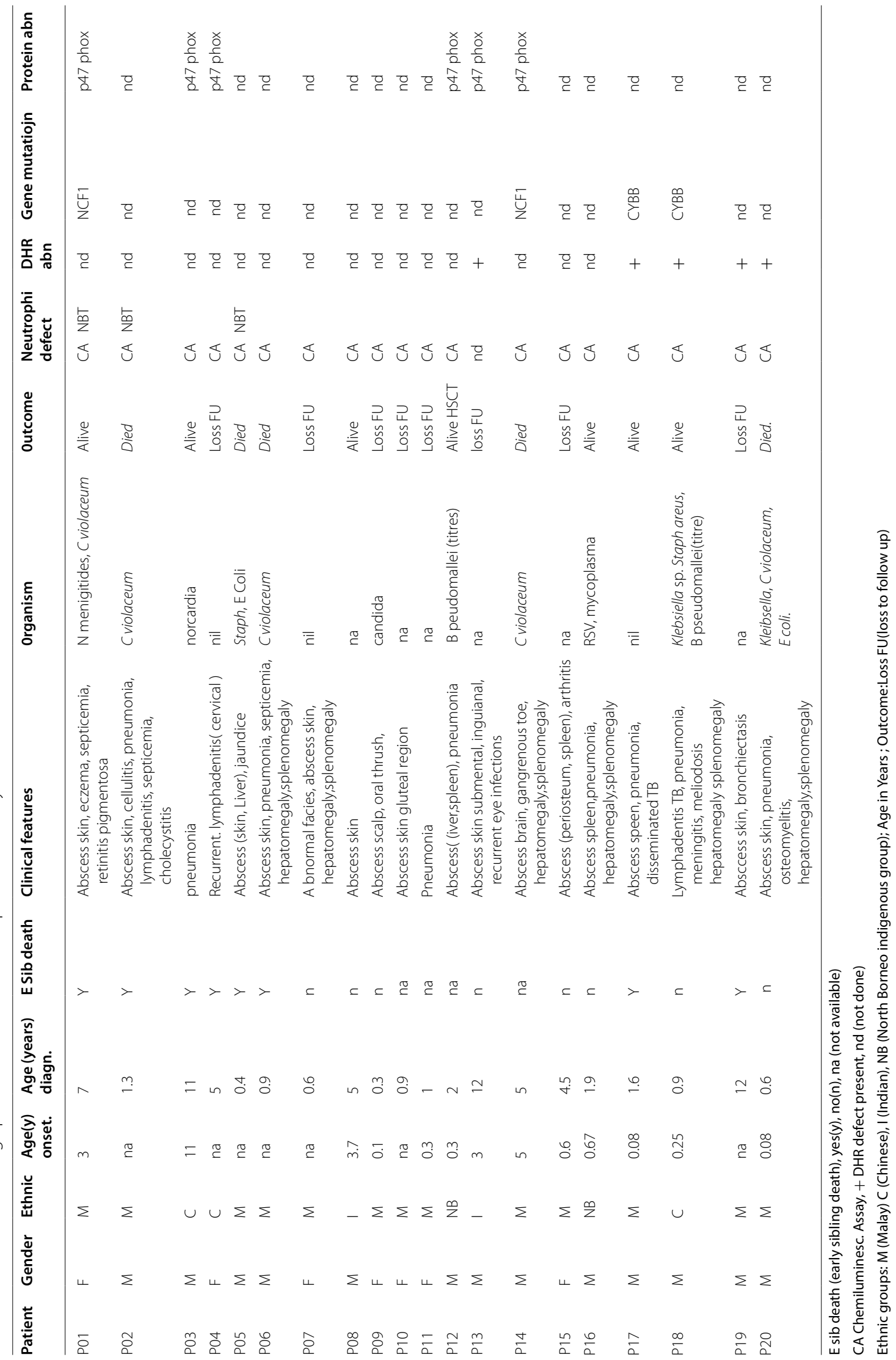


Table 2 Infections manifestation of CGD patients from Malaysia

\begin{tabular}{ll}
\hline Site of Infections & $\begin{array}{l}\text { Number } \\
\text { of patients } \\
(\%)\end{array}$ \\
\hline Abscess & $16(80)$ \\
Skin & 10 \\
Spleen & 3 \\
Liver & 3 \\
Bone & 1 \\
Brain & 1 \\
Muscle & 1 \\
Lung infections (pneumonia/abscess) & $10(50)$ \\
Hepatosplenomegaly & $6(30)$ \\
Septicemia & $3(15)$ \\
Meningitis & $1(5)$ \\
Lymphadenitis & $3(15)$ \\
Eye infection & $1(5)$ \\
Retinitis pigmentosa \& discoid lupus & $1(5)$ \\
Osteomyelitis & $1(5)$ \\
Arthritis & $1(5)$ \\
Oral candidiasis & $2(5)$ \\
\hline
\end{tabular}

Table 3 Types of microorganism in CGD patients from Malaysia

\begin{tabular}{ll}
\hline Organism & $\begin{array}{l}\text { Frequency } \\
\mathbf{n}(\%)\end{array}$ \\
\hline Chromobacterium violaceum & $5(25)$ \\
Burkholderia pseudomallei (titre) & $2(10)$ \\
Staphylococcus spp. & $2(10)$ \\
Klebsiella & $2(10)$ \\
Candida* & $2(10)$ \\
Nocardia & $1(5)$ \\
RSV & $1(5)$ \\
Neisseria meningitidis & $1(5)$ \\
Ecoli & $1(5)$ \\
Mycoplasma & $1(5)$ \\
\hline
\end{tabular}

*Oral candidiasis in both patient

was seen in France (88 out of 97 patients, 90.7\%) [18]. Predominant mode of autosomal recessive inheritance is seen in reports from India, Iran, Turkey, Israel and Saudi Arabia [9, 21-24]. It is noteworthy that a study done in a province in Saudi Arabia reported that all of their patients were autosomal recessive inheritance with a point prevalence of 6.4 per 100,000, the highest being reported up to 2009 in the literature [24]. Positive family history is seen in $40 \%$ of the Malaysian series which is higher in large reports from China $28 \%$ or Italy $35 \%$ [17, 25]. We could not conclude that there is a preponderance for autosomal recessive CGD (AR CGD) over X-linked
Table 4 Proportion(\%) of CGD with high or low Immune parameters in Malaysian patients with CGD

\begin{tabular}{llll}
\hline Immune parameters & $\begin{array}{l}\text { High levels* } \\
\mathbf{N}(\%)\end{array}$ & $\begin{array}{l}\text { Normal levels } \\
\mathbf{N}(\%)\end{array}$ & $\begin{array}{l}\text { Low levels*** } \\
\mathbf{N}(\%)\end{array}$ \\
\hline $\begin{array}{llll}\text { Lymphocyte subsets } \\
\text { CD3+/T cells }(\mathrm{N}=15)\end{array}$ & $7(46.6 \%)$ & $7(46.6)$ & $1(6.7 \%)$ \\
CD4+/Th cells $(\mathrm{N}=11)$ & $3(27.3 \%$ & $4(36.4)$ & $4 .(36.4 \%)$ \\
CD8 /Tc cells $(\mathrm{N}=11)$ & $4(36.4 \%)$ & $5(45.5)$ & $2(18.2)$ \\
B cell $(\mathrm{N}=15)$ & $3(20 \%)$ & $8(53.3 \%)$ & $4(26.6 \%)$ \\
Serum immunoglobulins & & & \\
$\operatorname{lgG}(\mathrm{N}=15$ & $11(73)$ & $3(20)$ & $1(6)$ \\
$\lg \mathrm{N}(\mathrm{N}=14)$ & $12(86)$ & $2(14.2)$ & 0 \\
$\lg M(\mathrm{~N}=15)$ & $8(53)$ & $7(47)$ & 0 \\
\hline
\end{tabular}

*Above normal range for age matched healthy children

**Below normal range for age matched healthy children

Normal \& high level lgG. 14/15 (93.3\%) CD3+ cells 14/15(93.3\%)

IgA. 14/14. (100\%) CD4+ cells 7/11 (63.6\%)

IgM. 15/15. (100\%) CD8+ cells 9/11 (81.8\%)

CGD (XL CGD) in our cohort in view of limited genetic mutational analysis performed. Interestingly, 4 of 6 (66\%) cases were with p47phox mutation, a marker of AR CGD defect, were males. Further data on mutational analysis will be needed to confirm if indeed there is a preponderance of AR CGD over XL CGD in Malaysia.

Abscesses are the most common presentation, unlike most other series where pneumonia is the commonest $[2,18,20,22]$. Pneumonia constitutes only $50 \%$ in our series making it the second most common presentation. One of the CGD patients had bronchiectasis as a sequela. Bronchiectasis is not a common finding amongst those with lung infections [21]. Brain abscess, a very uncommon presentation, is present in our series. Such presentation has been reported in another series [2, 23]. Lymphadenitis was the most common clinical presentation in some CGD series. However, in the Malaysian cohort, it is the third most common presentation $[8,19,21,24]$. Hepatosplenomegaly is also one of the common physical findings (30\%) in this series.

In term of infectious organisms, patients with CGD are prone to catalase-positive bacteria including $C$. violaceum. It is a gram-negative facultative anaerobe which is catalase positive dominating a variety of ecosystem in tropics and sub-tropical regions. It is a rare infection in human with less than 200 cases reported in the literature $[27,28]$. However, they can have a fulminating presentation with a high mortality [29]. Infection in human was first documented in Malaysia (1927), later Singapore, Vietnam, Thailand, Sri Lanka, Taiwan, Hong Kong, India, Australia, Southeast region of the US and Latin America (Brazil /Argentina) [28, 31]. 
Earlier reports indicated that $C$. violaceum infection in CGD patients as being rare with only one of 368 patients between 1993 and 1997 reported in the US Registry [2]. It is notable that Malaysia had 2 case reports of $C$. violaceum in CGD patients, first in 1994 and second in 2008 [4, 26]. More cases were reported in a review of children with invasive $C$. violaceum infection between 1971 and 2005 by Sirinavin et al., whereby out of 25 children with invasive $C$, violaceum infection, $36 \%$ were afflicted with CGD [30]. However, when considering proportion of CGD patients with C. violaceum infection, it was estimated at $42.9 \%$ for Thailand [7] and and $25 \%$ for Malaysia [present study]. In the present study, CGD patients are likely to succumb to $C$. violaceum infection. Mortality for all C. violaceum infected patients varies from 53 to $80 \%$, with higher risk in disseminated form of infection [29]. The mortality rate of CGD patients with C. violaceum infection is very much lower (7\%) in the Southeast US [27, 31] as compared to Malaysia at $80 \%$ (present study).

The next common infection was Burkholderia pseudomallei, a Gram-negative bacillus commonly found in soil and muddy water, presenting as melioidosis. Both of our patients with this infection survived with one having undergone HSCT. Other studies reported Staphylococcus spp. as the most common organism isolated among their CGD patients [18, 19]. However, Staphylococcus spp. infection only constitutes $10 \%$ of our series. Salmonella spp. was noted as the most common pathogen isolated from CGD patients with septicemia [2], however, this is not seen in our cohort.

Several studies have indicated fungal infections as the predominant organisms in their CGD patients with Aspergillus spp. being the predominant fungi isolated [9, 22, 23]. However, Aspergillus spp. was not isolated in our patients' samples. Instead, Candida spp. and Nocardia were isolated in our laboratory.

Mycobacterium tuberculosis infection afflicted a significant proportion of CGD in Sri Lanka, China and South East Asia [8, 17, 23]. Pulmonary tuberculosis is seen in $77 \%$ of CGD in Sri Lanka and $31.7 \%$ of CGD in Iran $[8,21]$. Tuberculosis did not occur as frequently in our series with only 2 (10\%) recorded, each of them had lymphadenitis and the other had a disseminated form of tuberculosis. Complications of BCG vaccination are also encountered in CGD case series as in 2 reports, with 53 and $64 \%$ of CGD vaccinated respectively resulting with infectious complication mainly localized around the injection sites $[17,32]$.

Patients with long standing CGD may develop noninfectious inflammatory complications. Previous studies had indicated various non-infectious inflammatory complications that occurred at different sites of the body. The manifestations included autoimmune manifestations, organ obstruction and granuloma formation. In one study, autoimmune phenomena occurred in about $50 \%$ of their CGD patients and the manifestations included inflammatory bowel disease, reactive arthritis, idiopathic thrombocytopenia and autoimmune hepatitis [22]. Lupus syndrome was also reported in some of the patients [2]. We recorded one patient with retinitis pigmentosa and discoid lupus. Chorioretinitis had been reported in the case series from Israel [23]. The non-infectious inflammatory complications should be actively sought out during the serial clinic follow ups.

The serum immunoglobulin level is typically hypergammaglobulinemic in CGD which is ascribed to infections by bacteria and fungi [33, 34]

An interesting facet of our lymphocyte subset analysis revealed that all of the $4(38 \%)$ of CGD with CD4 lymphopenia ended in a demise with $C$. violaceum infection. We cannot hypothesize whether $C$. violaceum is the cause of or the effect of CD4+lymphopenia in this Malaysian CGD series. The answer would come from further studies.

Prevention of infectious complications of CGD includes prophylaxis with appropriate antimicrobial agents; prophylaxis which includes trimethoprimsulfamethoxazole at $5 \mathrm{mg} / \mathrm{kg} /$ day (based on TMP component) and itraconazole at $5 \mathrm{mg} / \mathrm{kg} /$ day up to $100 \mathrm{mg}$ daily (if body weight $<50 \mathrm{~kg}$ ), or $200 \mathrm{mg}$ daily if body weight $>50 \mathrm{~kg}$ [36]. Interferon gamma is not available in Malaysia. The frequency of allogeneic HSCT as curative treatment option for CGD has increased since 2006 worldwide. The largest retrospective review on the outcome of HSCT on 712 patients with CGD demonstrated good survival outcome, low incidence of graft failure and mortality in all ages [37].

The allogenic HSCT in Malaysian government healthcare service has just recently started for PID in Malaysia and a patient (P12) from this cohort was successfully underwent HSCT with a matched sibling donor [13].

The overall survival of CGD is $90 \%$ stretched well to adulthood [25]. Others quoted as $81 \%$ with long term survival [18]. However, the survival rate is lower in developing countries. The mortality of the patients that we could follow up was $25 \%$ which was lower than India (35\%) and Sri Lanka 38\% [ but higher than the European cohort 20\%] [8, 9, 18]. Previous study demonstrated strong association between residual related reactive oxygen intermediates (ROI) and survival of patients with CGD, where those with little residual production of ROI may fare worse in the severity of illness and survival outcome [38] 


\section{Conclusion}

We have shown that CGD is prevalent in Malaysia and that similar prevalence could occur in South East Asia region. Recurrent abscesses are more frequently observed than pneumonia in Malaysia. Chromobacterium violaceum infection and melioidosis are being seen more often in tropical region with heavy rainfall throughout the year. A high index of suspicion is needed to detect $C$. violaceum infection in a CGD child who is admitted in severely ill state. Conversely, diagnosis CGD should be excluded when confronted with a previously healthy child with C. violaceum sepsis in SE Asia region. Determining lymphocyte immunophenotype for idiopathic CD4+lymphopenia in CGD with C. violaceum infection has added value for its association with mortality.

\section{Acknowledgements}

We would like to thank the Director General of Health Malaysia for his permission to publish this article. We thank all the 7 hospitals involved especially the nursing staffs and doctors. We also like to thank all the participating laboratories.

\section{Authors' contributions}

$L M N, A H A L, I H I, R M N, A A W, I J A H$ and $A A$ were involved in the conceptualization and design of the study, acquisition and analysis of data and writing of the manuscript. NBA, AMR, ZTZ, NZ, KAZ, FB, LJK, TN, FMJ, DN, $I \mathrm{H}, \mathrm{BBSAA}, \mathrm{HAL}, \mathrm{MAZA}, \mathrm{SMM}$, and IFH were involved in the recruitment of patients and acquisition of study and data curation. LMN, AAW, AHAL and IHI were involved in the writing of the original draft.

\section{Funding}

Research grant (RU) 1001/CIPPT/812036 of Universiti Sains Malaysia (USM).

\section{Availability of data materials}

All data generated or analyzed in this study and included in this article are available from the corresponding author on a reasonable request.

\section{Declarations}

\section{Ethics approval}

Ethical approval for this study was obtained from the Medical Research and Ethical Committee (MREC) Ministry of Health Malaysia (NMRR-09-284-3887) and Human Research Ethics Committee of Universiti Sains Malaysia.

\section{Consent for publication}

Not applicable as this is a retrospective study based on selected aspects of patients' clinical summary (from participating hospitals in Malaysia) transferred to a separate database record kept by the corresponding author. Individual case cannot be identified in manuscript. There were no interventional procedures other than what is required by attending pediatrician for diagnosis and management

\section{Competing interests}

The authors declare that they have no competing /conflicting interests.

\section{Author details}

${ }^{1}$ Department of Paediatrics, Hospital Tunku Azizah, Ministry of Health Malaysia, Kuala Lumpur, Malaysia. ${ }^{2}$ Department of Paediatrics, UKM, Kuala Lumpur, Malaysia. ${ }^{3}$ Pantai Hospital, Kuala Lumpur, Malaysia. ${ }^{4}$ Department of Paediatrics, Faculty of Medicine and Health Sciences, Universiti Putra Malaysia, Selangor, Malaysia. ${ }^{5}$ Universiti Kuala Lumpur, Kuala Lumpur, Malaysia. ${ }^{6}$ Department of Medical Microbiology and Immunology, Universiti Kebangsaan Malaysia Medical Centre, Kuala Lumpur, Malaysia. ${ }^{7}$ Primary Immunodeficiency Group, Cluster of Regenerative Medicine, Advanced Medical and Dental Institute, Universiti Sains Malaysia, Kepala Batas, Penang, Malaysia. ${ }^{8}$ Primary
Immunodeficiency Unit, Institute for Medical Research, Kuala Lumpur, Malaysia. ${ }^{9}$ Formerly At International Islamic University, Kuantan, Malaysia. ${ }^{10}$ Institute for Medical Research, Kuala Lumpur, Malaysia. ${ }^{11}$ Al Islam Specialist Hospital, Previously At Institute of Pediatrics, Hospital Kuala Lumpur, Kuala Lumpur, Malaysia. ${ }^{12}$ Sunway Medical Centre, Petaling Jaya, Selangor, Malaysia. ${ }^{13}$ Institute of Pediatrics, Hospital Kuala Lumpur, Kuala Lumpur, Malaysia. ${ }^{14} \mathrm{KPJ}$ Kuching Specialist Hospital, Kuching, Sarawak, Malaysia. ${ }^{15}$ Sarawak General Hospital, Kuching, Sarawak, Malaysia. ${ }^{16}$ Department of Paediatrics, Faculty of Medicine, Universiti Kebangsaan Malaysia Medical Centre, Kuala Lumpur, Malaysia. ${ }^{17}$ Cluster of Life Sciences, Advanced Medical and Dental Institute, Universiti Sains Malaysia, Kepala Batas, Penang, Malaysia. ${ }^{18} \mathrm{Gleneagles}$ Hospital, Kuala Lumpur, Malaysia. ${ }^{19}$ Faculty of Medicine, University Malaya, Kuala Lumpur, Malaysia. ${ }^{20}$ Hospital Sultanah Bahiyah, Alor Setar, Kedah, Malaysia. ${ }^{21}$ Hospital Serdang, Serdang, Selangor, Malaysia. ${ }^{22} \mathrm{Hospital}$ Tuanku Ja'afar, Seremban, Negeri Sembilan, Malaysia. ${ }^{23}$ Sarawak General Hospital, Kuching, Sarawak, Malaysia.

Received: 27 December 2020 Accepted: 3 May 2021

Published online: 17 May 2021

References

1. Tangye SG, Al-Herz W, Bousfiha A, et al. Human inborn errors of immunity: 2019 update on the classification from the international union of immunological societies expert committee. J Clin Immunol. 2020;40:24-64.

2. Winkelstein JA, Marino MC, Johnston RB, Boyle J, Curnutte J, Gallin J, et al. Chronic granulomatous disease report on a national registry of 368 patients. Medicine. 2000;79:155-69.

3. Abd Hamid IJ, Azman NA, Gennery AR, Mangantig E, Hashim IF, Zainudeen ZT. Systematic review of primary immunodeficiency diseases in Malaysia: 1979-2020. Front Immunol. 2020;11:1923. https://doi.org/10. 3389/fimmu.2020.01923.

4. Noh LM, Noah RM, Wu LL, Nasuruddin BA, Junaidah E, Ooi CP, et al. Chronic granulomatous disease-a report in two Malay families. Singapore Med J. 1994;35:505-8.

5. Noh LM, Nasuruddin BA, Abdul Latiff AH, Noah RM, KamarulAzahar MR, Norzila MZ, et al. Clinical-epidemiological pattern of primary immunodeficiencies in Malaysia 1987-2006: a 20 year experience in four Malaysian hospitals. Med J Malaysia. 2013;68:13-7.

6. Lim DL, Thong BY, Ho SY, Shek LPC, Lou J, Leong KP, et al. Primary immunodeficiency diseases in Singapore - the last 11 years. Singapore Med J. 2003:44(11):579-86.

7. Benjasupattananan B, Simasathein T, Vichyanond P, Leungwedchakarn V, Visitsunthorn N, Pacharn P, et al. Clinical characteristic and outcome of primary immunodeficiencies in Thai children: an 18 year experience from a tertiary care center. J Clin Immunol. 2009;29:357-64.

8. Fernando SJA, Faiz NM, Handunneti SM, De Silva AD, Dasanayake WMDK, Wickramasinghe GD, et al. Preliminary study on CGD in Sri Lanka. Allergy Asthma Clin Immunol. 2018;17:14-37.

9. Rawat A, Singh S, Suri D, Gupta A, Saikia B, Minz RW, et al. Chronic granulomatous disease: two decades of experience from a tertiary care centre in North West India. J Clin Immunol. 2014;34:58-67.

10. Roos D, Kuijpers TW, Curnutte JT. Chronic granulomatous disease. In: Ochs HD, Edvard-Smith Cl, Puck JM, editors. Primary immunodeficiency disease: a molecular and genetic approach. New York: Oxford University Press; 2007. p. 534-40.

11. Zainudeen ZT, Hashim IF, Abd Hamid IJ. Chronic Granulomatous Disease. Malays J Paediatr Child Health. 2020;25:28-9.

12. Noah RM, Jais MR, Noh LM. Evaluation of variable parameters in neutrophil function test using chemiluminescence assay. Malays J Pathol. 1994;16:157-60.

13. Ismail IH, Jamli FM, Othman IS, Noh LM, Abdul Latiff AH. Malaysia's first transplanted case of chronic granulomatous disease: the journey of overcoming obstacles. Children (Basel). 2016;17(3):9. https://doi.org/10. 3390/children3020009.

14. Salaria M, Singh S, Kumar L, Datta U, Sehgal S. Chronic granulomatous disease. Indian Pediatr. 1999;36:594-6. 
15. Ma JS, Chen PY, Fu LS, Chi CS, Huang YF, Lin CY, et al. Chronic granulomatous disease: a case report. J Microbiol Immunol Infect. 2000:33:118-22

16. Gill HK, Kumar HC, Dhaliwal JS, Zabidi F, Sendut IH, Noah RM, et al. Defining p47-phox deficient Chronic Granulomatous Disease in a Malay family. Asian Pac J Allergy Immunol. 2012;30:313-20.

17. Wu J, Wang WF, Zhang Y, Chen T. Clinical features and genetic analysis of 48 patients with chronic granulomatous disease in a single center study from Shanghai China (2005-2015): new studies and literature review. J Immunol Res. 2017. https://doi.org/10.1155/2017/8745254.

18. van den Berg JM, van Koppen E, Ahlin A, Belohradsky BH, Bernatowska E, Corbeel L, et al. Chronic granulomatous disease: the European Experience. PLoS ONE. 2009;4:e5234. https://doi.org/10.1371/journal. pone.0005234.

19. Bortoletto P, Lyman K, Camacho A, Fricchione M, Khanolkar A, Katz BZ, et al. Chronic granulomatous disease: a large, single-center US experience. Pediatr Infect Dis J. 2015;34:1110-4.

20. Magnani A, Brosselin $P$, Beautè J, de Vergnes $N$, Mouy R, Debrè $M$, et al. Inflammatory manifestations in a single-center cohort of patients with chronic granulomatous disease. J Allergy Clin Immunol. 2014;134:655-62.

21. Movahedi M, Aghamohammadi A, Rezaei N, Shahnavaz N, Jandaghi AB, Farhoudi A, et al. Chronic granulomatous disease: a clinical survey of 41 patients from the Iranian primary immunodeficiency registry. Int Arch Allergy Immunol. 2004;134:253-9.

22. Köker MY, Camcioglu Y, van Leeuwen K, Kilic SS, Barlan I, Yilmaz M, et al. Clinical, functional and genetic characterization of chronic granulomatous disease in 89 Turkish patients. J Allergy Clin Immunol. 2013;132:1156-63.

23. Wolach B, Gavrieli R, de Boer M, van Leeuwen K, Berger-Achituv S, Satuber T, et al. Chronic granulomatous disease: clinical, functional, molecular, and genetic studies. The Israeli experience with 84 patients. Am J Hematol. 2017;92:28-36.

24. Suliaman F, Amra N, Sheikh S, Almuhsen S, Alsmadi O. Epidemiology of chronic granulomatous disease of childhood in Eastern Province, Saudi Arabia. Pediatr Asthma Allergy Immunol. 2009;22:21-6.

25. Martire B, Rondelli R, Soresina A, Pignata C, Broccoletti T, Finocchi A, et al. Clinical features, long-term follow-up, and outcome of a large cohort of patients with chronic granulomatous disease: an Italian multi center study. Clin Immunol. 2008;126:155-64.

26. Sureisen M, Choon SK, Tai CC. Recurrent Chromobacterium violaceum infection in a patient with chronic granulomatous disease. Med J Malays. 2008:63:346-7.

27. Frawley AA, Powell L, McQuiston JR, Gulvik CA, Beque RE. Necrotizing pneumonia caused by Chromobacterium violaceum: report of a rare human pathogen causing disease in an immunodeficient child. Am J Trop Med Hyg. 2018;9:164-7.

28. Lee PP, Lau YL. Endemic infections in Southeast Asia provide new insights to the phenotypic spectrum of primary immunodeficiency disorders. Asia Pacific J Allergy Immunol. 2013;31:217-26.

29. Bansie R, Harkisoen S, Lachman V, Fat ELA, Ramdhani N, van Laar JAM. rare infection in the tropics that is not uncommon in cases of chronic granulomatous disease. Access Microbiol. 2019;18:39. https://doi.org/10. 1099/acmi.0.000039.

30. Sirinavin S, Techasaensiri C, Benjaponpitak S, Pornkul R, Vorachit M. Invasive Chromobacterium violaceum infection in children: case report and review. Pediatr Infect Dis J. 2005:24:559-61.

31. Meher-Homji Z, Mangalore RP, Johnson PDR, Chua KYL. Chromobacterium violaceum infection in chronic granulomatous disease: a case report and review of the literature. JMM Case Rep. 2017;4:e005084. https://doi.org/ 10.1099/jmmcr.0.005084.

32. Bustamante J, Aksu G, Vogt G, de Beaucoudrey L, Genel F, Chapgier A, et al. BCG-osis and tuberculosis in a child with chronic granulomatous disease. J Allergy Clin Immunol. 2007;120:32-8.

33. Holland SM. Chronic granulomatous disease. Hematol Oncol Clin North Am. 2013;27:89-99.

34. Janeway CA, Craig J, Davidson M, Downey W, Gitlin D, Sullivan JC. Hypergammaglobulinemia associated with severe recurrent and chronic non-specific infection. Am J Dis Child. 1954;88:388-92.

35. Leiding JW, Holland SM. Chronic granulomatous disease. In: Sullivan KE, Steihm ER, editors. Stiehm's immune deficiency. The Netherlands: Elsevier; 2014. p. 633-48.

36. Thomsen IP, Smith MA, Holland SM, Creech CB. A comprehensive approach to the management of children and adults with chronic granulomatous disease. J Allergy Clin Immunol Pract. 2016;4:1082-8.

37. Chiesa R, Wang J, Blok H, Hazelaar S, Neven B, Moshous D, et al. Hematopoietic cell transplantation in chronic granulomatous disease: a study of 712 children and adults. Blood. 2020;136:1201-11.

38. Kuhns DB, Alvord WG, Heller T, Feld JJ, Pike KM, Marciano BE, et al. Residual NADPH oxidase and survival in chronic granulomatous disease. N Engl J Med. 2010;363:2600-10.

\section{Publisher's Note}

Springer Nature remains neutral with regard to jurisdictional claims in published maps and institutional affiliations.
Ready to submit your research? Choose BMC and benefit from:

- fast, convenient online submission

- thorough peer review by experienced researchers in your field

- rapid publication on acceptance

- support for research data, including large and complex data types

- gold Open Access which fosters wider collaboration and increased citations

- maximum visibility for your research: over $100 \mathrm{M}$ website views per year

At BMC, research is always in progress.

Learn more biomedcentral.com/submissions 